\title{
Vzácný allanpringit - produkt alterace fluorwavellitu z lomu Milina u Zaječova (Česká republika)
}

\author{
Rare allanpringite - alteration product of fluorwavellite from Milina quarry near Zaječov \\ (Czech Republic)

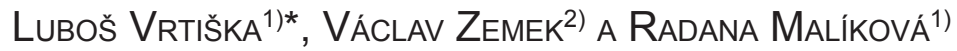 \\ ${ }^{1) M i n e r a l o g i c k o-p e t r o l o g i c k e ́ ~ o d d e ̌ l e n i ́, ~ N a ́ r o d n i ́ ~ m u z e u m, ~ C i r k u s o v a ́ ~ 1740, ~} 19300$ Praha 9 - Horní Počernice; \\ *email: lubos.vrtiska@nm.cz \\ 2)Domašín 48, 25801 Vlašim
}

VRtišKa L, Zemek V, MaLíková R (2020) Vzácný allanpringit - produkt alterace fluorwavellitu z lomu Milina u Zaječova (Česká republika). Bull Mineral Petrolog 28(1): 126-131 ISSN 2570-7337

\begin{abstract}
A very rare phosphate allanpringite was found in the abandoned quarry Milina near Zaječov, Czech Republic in Ordovician sediments of the Barrandian area. Allanpringite forms yellow powder and earthy aggregates. In a more detailed study using SEM microscope, allanpringite forms rod-shaped and tabular crystals. Its origin is associated with alteration of fluorwavellite. Empirical formula of the allanprigite is $\left(\mathrm{Fe}_{270} \mathrm{Al}_{0.24}\right)_{\Sigma 2.94}\left(\mathrm{PO}_{4}\right)_{2.00}(\mathrm{OH})_{2.83} \cdot 5 \mathrm{H}_{2} \mathrm{O}$ and refined unitcell parameters are a 9.774(5), b 7.361(3), c 17.826(8) $\AA, \beta 92.2(6)^{\circ}$ and $V$ 1281.5(9) $\AA^{3}$. Allanpringite was found in association with jarosite, variscite and partly altered fluorwavellite.
\end{abstract}

Key words: allanpringite, fluorwavellite, jarosite, phosphate occurrence, chemical composition, powder X-ray diffraction data, unit-cell parameters, Ordovician sediments, Milina, Czech Republic

Obdrženo 27. 4. 2020; prijjato 5. 6. 2020

\section{Úvod}

Vzácný sekundární monoklinický fosfát trojmocného železa - allanpringit, $\mathrm{Fe}^{3+}{ }_{3}\left(\mathrm{PO}_{4}\right)_{2}(\mathrm{OH})_{3} \cdot 5 \mathrm{H}_{2} \mathrm{O}$, byl jako nový minerální druh popsán Kolitschem et al. (2006). Typovou lokalitou je opuštěný železnorudný důl Mark u Essershausenu $v$ Německu, kde byl allanpringit nalezen $v$ haldovém materiálu. Minerál byl pojmenován po australském mineralogu Allanu Pringovi. Typová lokalita byla donedávna zároveň jediným známým výskytem na světě. $V$ loňském roce byla nově publikována data pro allanpringit $\mathrm{z}$ historických vzorků fosfátů z Krušné Hory u Berouna (Vrtiška et al. 2019), kde tvoří žluté práškovité agregáty, které vyplňují prostory mezi alterovanými jehlicemi bílého fluorwavellitu. $V$ rámci výzkumu sekundárních fosfátových mineralizací České republiky byl nově zjištěn také na vzorku s fluorwavellitem, variscitem a jarositem z historického lomu Milina u Zaječova.

\section{Geologie lokality}

Historický kamenolom s výskytem allanpringitu (obr. 1) se nachází na nenápadném hřbítku Milina s kótou $563 \mathrm{~m} \mathrm{n}$. m. mezi Olešnou a Zaječovem (GPS souřadnice $\left.49^{\circ} 46^{\prime} 18.099^{\prime \prime} \mathrm{N} 13^{\circ} 48^{\prime} 52.232^{\prime} \mathrm{E}\right)$ cca $10 \mathrm{~km} \mathrm{jz}$. od Hořovic. Tento lom je mineralogům znám více než 130 let převážně hojným výskytem hydratovaných fosfátů vázaných na pukliny $v$ ordovických sedimentech. Bližší informace o zdejších minerálech včetně nově zjištěného jarositu shrnují Černý et al. (2015). Z geologického hlediska spadá Milina do tepelsko-barrandienské oblasti, která je zde reprezentována především svrchně kambrickými andezity, bazalty a jejich pyroklastiky náležícími strašickému komplexu, ordovickými bazalty (diabasy), pyroklastiky a tufy komárovského vulkanického komplexu a dále ordovickými sedimenty zastoupenými převážně křemennými pískovci, slepenci, silicity a jílovými břidlicemi. Samotná lokalita byla v minulosti otevřena několika menšími, v současné době zašlými zalesněnými lomy (obr. 2 a 3), které odkrývají nejvyšší část třenického souvrství, celou mocnost milinského a spodní část klabavského souvrství. Vznik těchto souvrství časově spadá do období spodního ordoviku. Třenické souvrst-

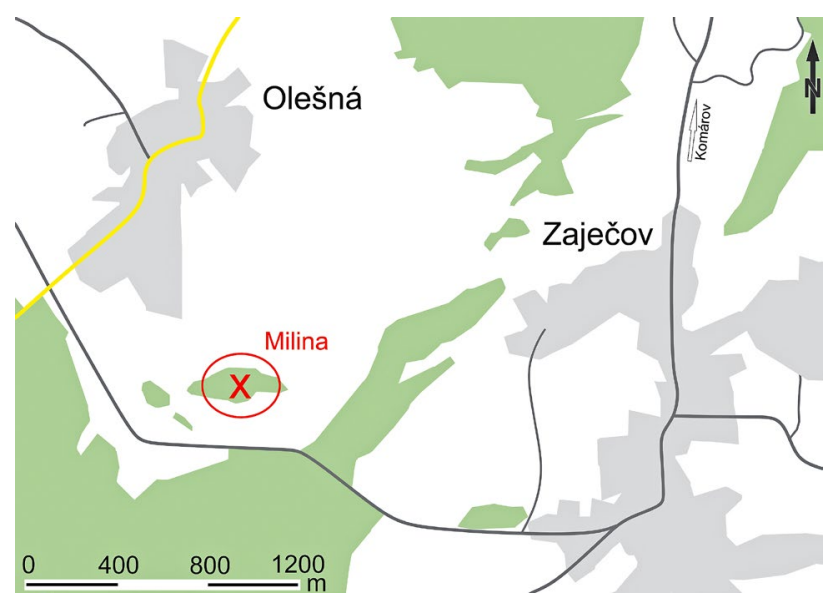

Obr. 1 Zjednodušená mapa s vyznačením pozice lokality Milina (zdroj www.mapy.cz). 
ví je zde zastoupeno převážně světlými šedozelenými hrubozrnnými drobami. Milinské souvrství, které zde dosahuje mocnosti asi $20 \mathrm{~m}$, je tvořeno lavicemi a deskami šedozelených a hnědočervených silicitů, navzájem oddělených tenkými vložkami jemnozrnných drob. $V$ nadloží těchto hornin vystupuje asi $5 \mathrm{~m}$ mocný sled rudohnědých drob, které směrem vzhůru přecházejí do rudohnědých prachovců klabavského souvrství (Mergl, Vohradský 2000).

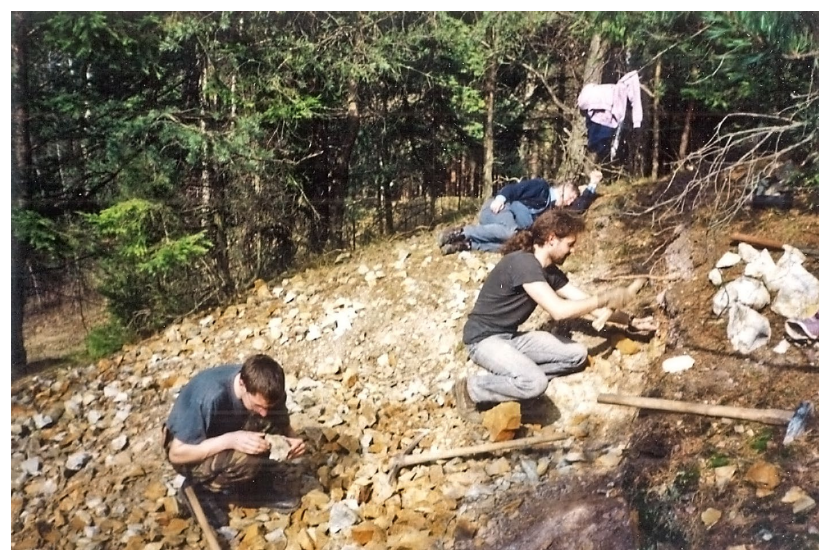

Obr. 2 Poloha ordovických hornin s výskytem allanpringitu v lomu Milina. Foto P. Jakubův, 1995.

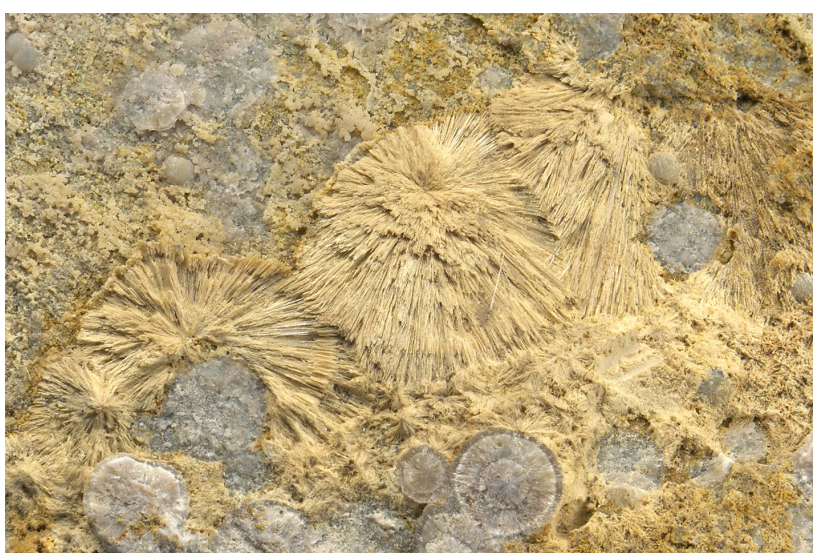

Obr. 4 Radiálně paprsčité agregáty fluorwavellitu z větší části nahrazeného okrovým allanpringitem spolu s bílými koncentrickými agregáty variscitu. Šírka záběru $30 \mathrm{~mm}$, foto L. Vrtiška.

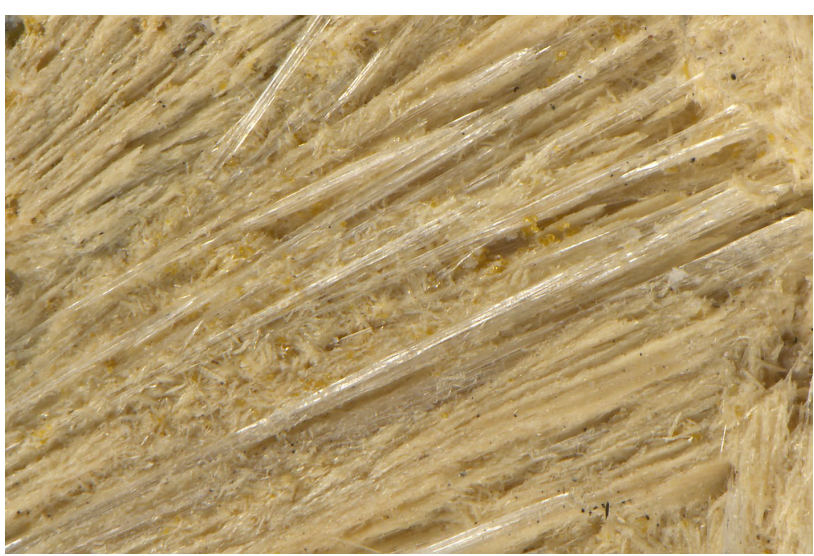

Obr. 6 Okrový allanpringit obrůstající nebo nahrazující jehlicovité krystaly fluorwavellitu. V dutinách mezi jehlicemi jsou patrné velmi drobné krystaly oranžového jarositu. Šírka záběru $3 \mathrm{~mm}$, foto L. Vrtiška.

\section{Metodika výzkumu}

Barevné mikrofotografie byly pořízeny pomocí mikroskopu Nikon SMZ 25 s digitální kamerou Nikon DS-Ri2 a funkce skládání obrazu za použití programu NIS Elements AR verze 4.20. Fotografie ve zpětně rozptýlených elektronech (BSE) byly pořízeny na elektronovém skenovacím mikroskopu Hitachi S3700-N (Národní muzeum, Praha).

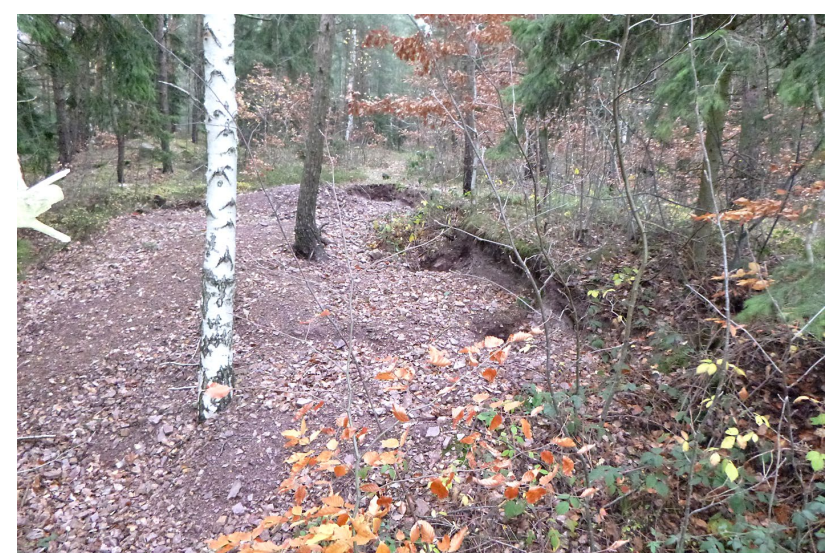

Obr. 3 Výchozy ordovických hornin v zašlém lomu Milina. Foto P. Černý, listopad 2017.

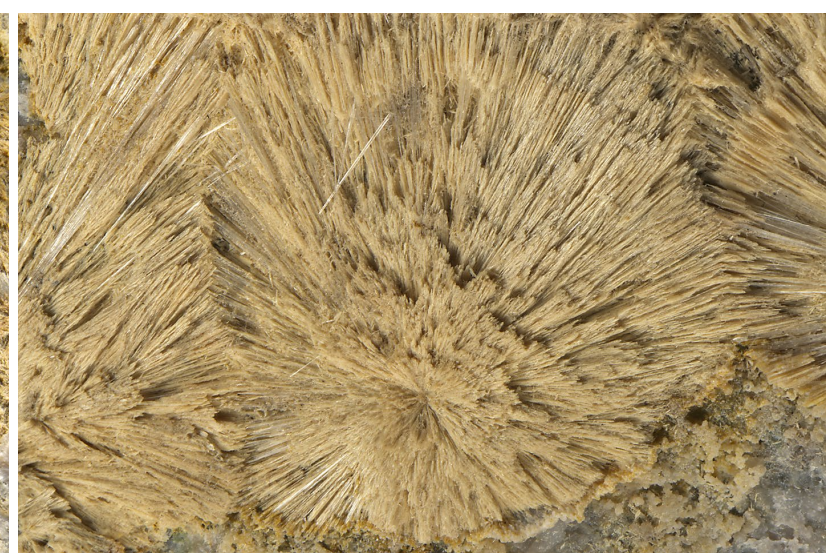

Obr. 5 Čiré jehlicovité krystaly fluorwavellitu alterované na okrový allanpringit. Šiřka záběru $13 \mathrm{~mm}$, foto L. Vrtiška.

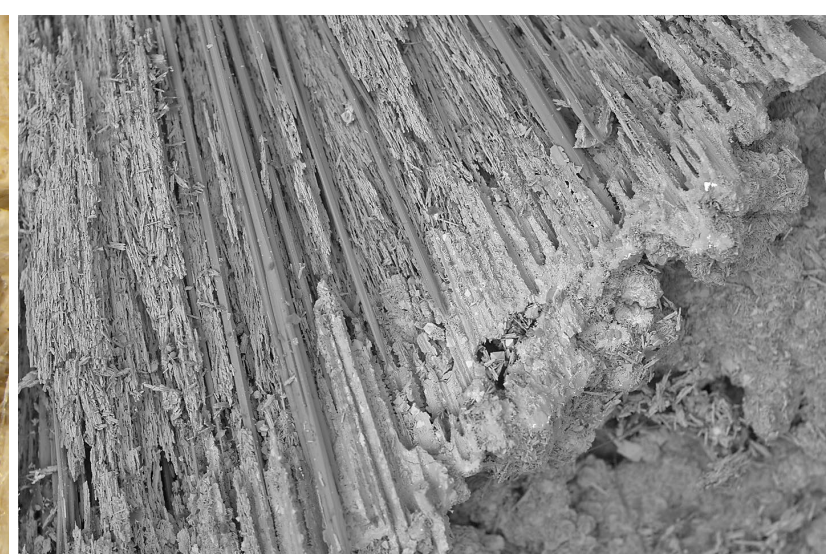

Obr. 7 Jehlice fluorwavellitu obrůstané či nahrazené krustami a tyčinkovitými agregáty allanpringitu. Šírka záběru $1.9 \mathrm{~mm}$, BSE foto L. Váchová. 
Rentgenová prášková difrakční data studovaných fází byla získána pomocí práškového difraktometru Bruker D8 Advance (Národní muzeum, Praha) s polovodičovým pozičně citlivým detektorem LynxEye za užití CuKa záření ( $40 \mathrm{kV}, 40 \mathrm{~mA})$. Práškové preparáty byly naneseny $v$ acetonové suspenzi na nosič zhotovený $z$ monokrystalu

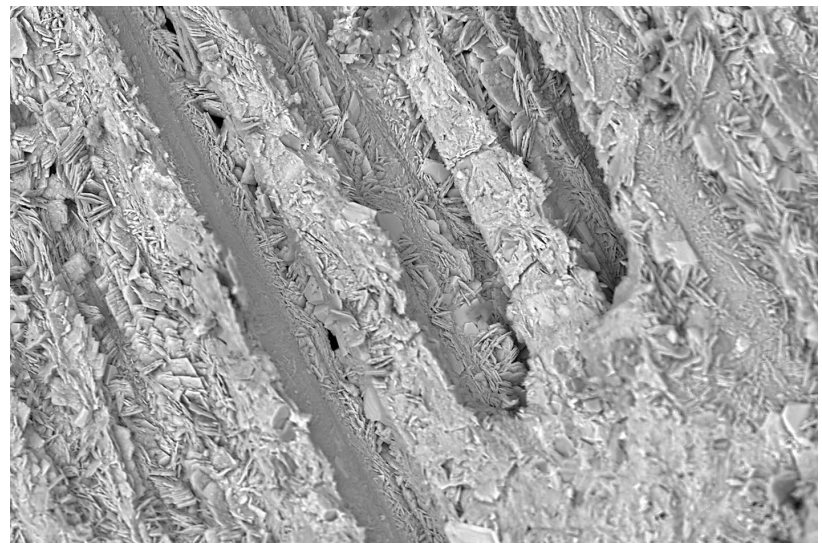

Obr. 8 Negativy po jehlicovitých krystalech (fluor)wavellitu tvořené krustami složenými z tabulkovitých krystalů allanpringitu. Šírka záběru $250 \mu \mathrm{m}$, BSE foto L. Váchová.

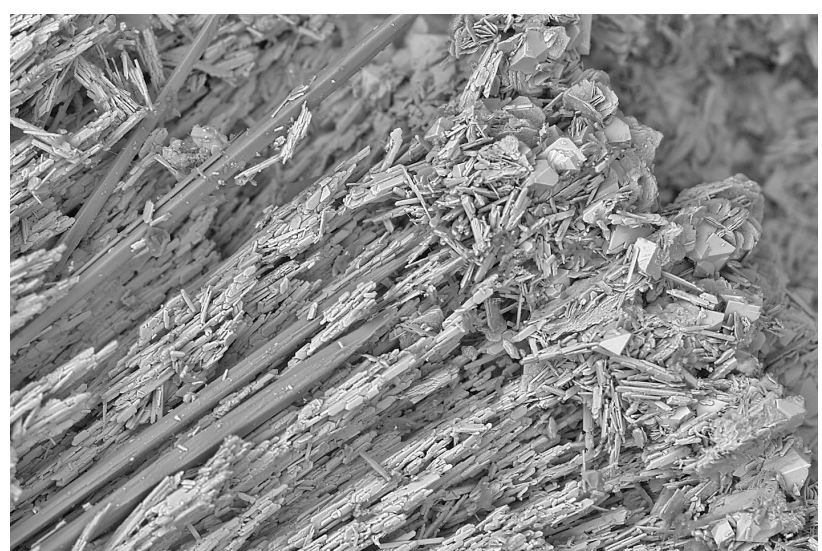

Obr. 10 Jehlice fluorwavellitu obrůstané či nahrazené krustami a tyčinkovitými agregáty allanpringitu s dipyramidálními krystaly jarositu. Šírka záběru 500 m, BSE foto L. Váchová. křemíku a následně pak byla pořizena difrakční data ve step-scanning režimu (krok $0.01^{\circ}$, načitací čas $8 \mathrm{~s} / \mathrm{krok}$ detektoru, celkový čas experimentu cca 15 hod.). Pozice jednotlivých difrakčních maxim byly popsány profilovou funkcí Pseudo-Voigt a zpřesněny profilovým fitováním v programu HighScore Plus. Mřižkové parametry byly

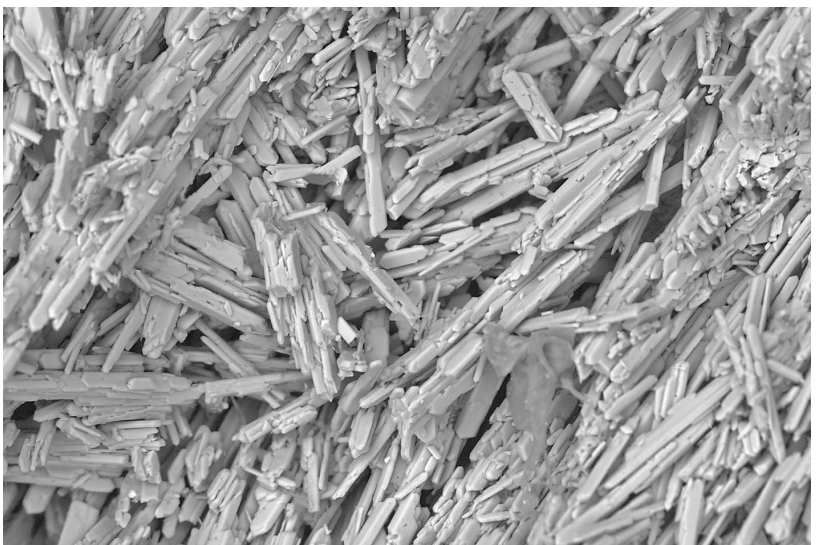

Obr. 9 Tyčinkovité agregáty složené z tabulkovitých krystalů allanpringitu. Šírka záběru $210 \mu \mathrm{m}$, BSE foto L. Váchová.

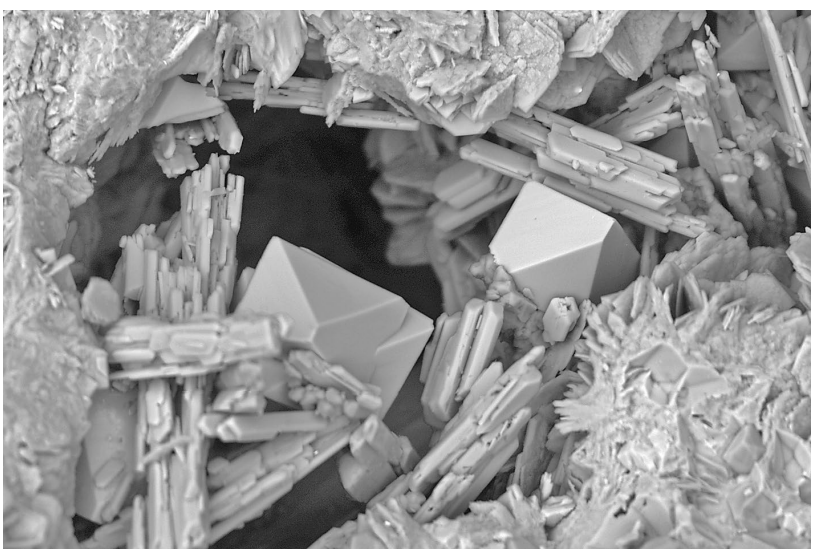

Obr. 11 Dipyramidální krystaly jarositu s tyčinkovitými agregáty allanpringitu. Šírka záběru $150 \mu \mathrm{m}$, BSE foto L. Váchová.

Tabulka 1 Rentgenová prášková data allanpringitu z Miliny

\begin{tabular}{rrrrrrrrrrrrrrrrrr}
\hline$h$ & $k$ & $l$ & $d_{o b s}$ & \multicolumn{1}{c}{$l_{\text {obs }}$} & $d_{\text {calc }}$ & \multicolumn{1}{c}{$h$} & $k$ & $l$ & $d_{\text {obs }}$ & $l_{\text {obs }}$ & $d_{c a l c}$ & \multicolumn{1}{c}{$h$} & $k$ & $l$ & $d_{\text {obs }}$ & $l_{\text {obs }}$ & $d_{c a l c}$ \\
\hline 0 & 0 & 2 & 8.828 & 100 & 8.907 & 2 & 2 & 1 & 2.891 & 4 & 2.889 & 3 & 3 & 1 & 1.9428 & $<1$ & 1.9428 \\
-1 & 0 & 1 & 8.641 & 25 & 8.706 & 3 & 1 & 2 & 2.797 & 5 & 2.794 & 3 & 3 & 2 & 1.9036 & $<1$ & 1.9044 \\
1 & 0 & 1 & 8.361 & 24 & 8.429 & -2 & 2 & 3 & 2.661 & 2 & 2.659 & 4 & 0 & 6 & 1.8509 & 1 & 1.8514 \\
1 & 1 & 0 & 5.840 & 4 & 5.878 & 2 & 2 & 3 & 2.611 & 3 & 2.610 & -3 & 2 & 7 & 1.7859 & $<1$ & 1.7864 \\
0 & 1 & 2 & 5.709 & $<1$ & 5.674 & 0 & 2 & 5 & 2.5658 & $<1$ & 2.5597 & -1 & 4 & 2 & 1.7747 & $<1$ & 1.7746 \\
-1 & 0 & 3 & 5.133 & 8 & 5.162 & -2 & 2 & 4 & 2.4790 & 1 & 2.4794 & 3 & 2 & 7 & 1.7360 & $<1$ & 1.7359 \\
-1 & 1 & 2 & 4.958 & 9 & 4.959 & 2 & 2 & 4 & 2.4269 & 2 & 2.4274 & -5 & 2 & 2 & 1.7054 & $<1$ & 1.7047 \\
1 & 1 & 2 & 4.861 & 24 & 4.855 & -1 & 3 & 1 & 2.3598 & 1 & 2.3615 & -5 & 2 & 3 & 1.6724 & 1 & 1.6721 \\
0 & 0 & 4 & 4.429 & 13 & 4.453 & -3 & 1 & 5 & 2.3238 & 1 & 2.3250 & -3 & 3 & 6 & 1.6531 & $<1$ & 1.6530 \\
1 & 1 & 3 & 4.107 & $<1$ & 4.130 & -4 & 1 & 1 & 2.3094 & 1 & 2.3089 & 2 & 2 & 9 & 1.6241 & 1 & 1.6244 \\
2 & 1 & 0 & 4.053 & 1 & 4.069 & -1 & 3 & 3 & 2.2169 & 1 & 2.2159 & 3 & 4 & 0 & 1.6014 & 1 & 1.6019 \\
0 & 2 & 0 & 3.698 & $<1$ & 3.680 & 2 & 3 & 1 & 2.1691 & 3 & 2.1714 & -3 & 4 & 2 & 1.5812 & 1 & 1.5818 \\
-1 & 1 & 4 & 3.585 & 3 & 3.590 & 2 & 1 & 7 & 2.1285 & $<1$ & 2.1273 & 2 & 2 & 10 & 1.5080 & $<1$ & 1.5080 \\
0 & 1 & 5 & 3.212 & 24 & 3.207 & -1 & 1 & 8 & 2.0994 & 5 & 2.0984 & 4 & 3 & 6 & 1.4780 & 1 & 1.4778 \\
3 & 0 & 1 & 3.181 & 2 & 3.181 & 2 & 3 & 3 & 2.0465 & 2 & 2.0452 & -1 & 5 & 1 & 1.4510 & $<1$ & 1.4515 \\
-2 & 1 & 4 & 3.063 & 1 & 3.053 & 4 & 2 & 0 & 2.0363 & 2 & 2.0346 & -1 & 5 & 2 & 1.4376 & $<1$ & 1.4379 \\
-1 & 2 & 3 & 3.000 & 1 & 2.997 & -1 & 3 & 5 & 1.9873 & 2 & 1.9874 & 4 & 0 & 10 & 1.4139 & $<1$ & 1.4135 \\
2 & 2 & 0 & 2.943 & 1 & 2.939 & 3 & 3 & 0 & 1.9584 & 2 & 1.9594 & & & & \\
\hline
\end{tabular}


zpřesněny metodou nejmenších čtverců pomocí programu Celref (Laugier, Bochu 2011).

Chemické složení studovaných fází bylo kvantitativně studováno pomocí elektronového mikroanalyzátoru Cameca SX100 (Národní muzeum Praha, analytik Z. Dolníček). Podmínky měření: WD analýza 15 kV, 10 nA, průměr svazku elektronů $5 \mu \mathrm{m}$. Použité standardy: apatit (PKa, CaKa), sanidin (SiKa, AlKa, KKa), klinoklas (AsLa), albit (NaKa), diopsid (MgKa), celestin (SKa, SrLa), rodonit (MnKa), $\mathrm{Sn}(\mathrm{SnL} \alpha)$, halit $(\mathrm{ClK} \alpha), \mathrm{TiO}_{2}(\mathrm{TiK} \alpha)$, vanadinit $(\mathrm{PbMa}), \mathrm{UO}_{2}(\mathrm{UMa})$, Th (ThM $\alpha), B i(B i M \alpha)$, hematit (FeKa), chalkopyrit (CuKa), Co (CoKa), ZnO $(\mathrm{ZnKa})$, baryt $(\mathrm{BaL} \beta)$, LiF $(\mathrm{FK \alpha})$, $\mathrm{Cr}_{2} \mathrm{O}_{3}(\mathrm{CrKa}), \mathrm{BN}(\mathrm{NK \alpha}), \mathrm{YVO}_{4}(\mathrm{YL \alpha})$. Obsahy výše uvedených prvků, které nejsou zahrnuty $v$ tabulkách, byly kvantitativně analyzovány, ale zjištěné obsahy byly pod detekčním limitem (cca $0.01-0.06 \mathrm{hm}$. \% vyjma Th, Zn a As, u nichž jsou cca $0.1-0.2 \mathrm{hm}$. $\%)$. Získaná data byla korigována za použití software PAP (Pouchou, Pichoir 1985).

\section{Allanpringit}

Vzorek s allanpringitem a doprovodnými minerály nalezl $v$ roce 1995 druhý autor (VZ) v zarostlém lomu Milina (obr. 2 a 3). Allanpringit na vzorku zelenošedé droby tvoří žluté, zdánlivě práškovité agregáty, které obrůstají či zcela nahrazují jehlicovité krystaly radiálně paprsčitého fluorwavellitu (obr. 4-6). Allanpringit tak místy zachovává tvar těchto agregátů, které dosahují velikosti do $12 \mathrm{~mm} v$ průměru. Při studiu vzorku ve zpětně rozptýlených elektronech (BSE) je patrné, že allanpringit tvoří perimorfózy po jehlicích fluorwavellitu v podobě krust, složených z drobných tabulkovitých krystalů o velikosti okolo $10 \mu \mathrm{m}$ (obr. 7 a 8). Tyto idiomorfní krystaly také částečně vyplňují prostory mezi perimorfózami. Tenké tabulovité krystaly místy srůstají do tyčinkovitých agregátů většinou subparalelních s relikty fluorwavellitových jehlic (obr. 9). Nejmladším minerálem studované asociace je jarosit, který tvoři dipyramidální, dokonale omezené krystaly do velikosti $30 \mu \mathrm{m}$, které narůstají na allanpringit (obr. 10 a 11).

Rentgenová prášková data allanpringitu z Miliny (tab. 1) odpovídají publikovaným údajům pro tento minerální druh (Kolitsch et al. 2006). Zpřesněné parametry jeho základní cely jsou v tabulce 2 porovnány s publikovanými údaji.

Při podrobném studiu chemického složení allanpringitu z Miliny (tab. 3) byly $v$ kationtové pozici zjištěny vedle dominantního $\mathrm{Fe}^{3+}(2.65-2.76$ apfu), také zvýšené obsahy $\mathrm{Al}(0.18-0.28 \mathrm{apfu})$ a minoritní obsahy $\mathrm{Ca}$ (do $0.003 \mathrm{apfu}$ ). $\mathrm{V}$ aniontové pozici byl zjištěn pouze $\mathrm{P}$. Empirický vzorec allanpringitu z Miliny Ize na bázi $\mathrm{P}=2$ apfu (průměr sedmi bodových analýz) vyjádřit jako $\left(\mathrm{Fe}_{2.70}\right.$ $\left.\mathrm{Al}_{0.24}\right)_{\Sigma 2.94}\left(\mathrm{PO}_{4}\right)_{2.00}(\mathrm{OH})_{2.83} \cdot 5 \mathrm{H}_{2} \mathrm{O}$.

Tabulka 2 Parametry základní cely allanpringitu pro monoklinickou prostorovou grupu $P 2, / n$

\begin{tabular}{rccc}
\hline & tato práce & Kolitsch et al. (2006) & Vrtiška et al. (2019) \\
\hline$a[\AA]$ & $9.774(5)$ & $9.777(3)$ & $9.778(2)$ \\
$b[\AA]$ & $7.361(3)$ & $7.358(2)$ & $7.352(3)$ \\
$c[\AA]$ & $17.826(8)$ & $17.830(5)$ & $17.833(4)$ \\
$\beta\left[{ }^{\circ}\right]$ & $92.2(6)$ & $92.19(4)$ & $92.17(4)$ \\
$V\left[\AA^{3}\right]$ & $1281.5(9)$ & $1281.7(6)$ & $1281.1(7)$ \\
\hline
\end{tabular}

Tabulka 3 Chemické složení allanpringitu z Miliny (hm. \%)

\begin{tabular}{lrrrrrrrr}
\hline & mean & 1 & 2 & 3 & 4 & 5 & 6 & 7 \\
\hline $\mathrm{CaO}$ & 0.03 & 0.03 & 0.00 & 0.03 & 0.03 & 0.04 & 0.04 & 0.03 \\
$\mathrm{Fe}_{2} \mathrm{O}_{3}$ & 45.28 & 44.83 & 44.44 & 45.45 & 44.67 & 45.79 & 46.71 & 45.06 \\
$\mathrm{Al}_{2} \mathrm{O}_{3}$ & 2.54 & 2.98 & 2.94 & 2.37 & 2.63 & 1.93 & 2.56 & 2.40 \\
$\mathrm{P}_{2} \mathrm{O}_{5}$ & 29.78 & 29.41 & 29.80 & 29.88 & 29.56 & 29.47 & 30.69 & 29.68 \\
$\mathrm{H}_{2} \mathrm{O}^{*}$ & 24.24 & 24.23 & 24.16 & 24.23 & 24.03 & 24.01 & 24.97 & 24.07 \\
\hline total & 101.88 & 101.48 & 101.34 & 101.96 & 100.92 & 101.24 & 104.97 & 101.24 \\
\hline $\mathrm{Ca}^{2+}$ & 0.002 & 0.003 & 0.000 & 0.003 & 0.003 & 0.003 & 0.003 & 0.003 \\
$\mathrm{Fe}^{3+}$ & 2.703 & 2.710 & 2.651 & 2.704 & 2.686 & 2.762 & 2.706 & 2.699 \\
$\mathrm{Al}^{3+}$ & 0.238 & 0.282 & 0.275 & 0.221 & 0.248 & 0.182 & 0.232 & 0.225 \\
\hline$\Sigma$ & 2.943 & 2.994 & 2.926 & 2.927 & 2.937 & 2.948 & 2.941 & 2.927 \\
\hline $\mathrm{P}^{5+}$ & 2.000 & 2.000 & 2.000 & 2.000 & 2.000 & 2.000 & 2.000 & 2.000 \\
\hline $\mathrm{OH}^{-}$ & 2.826 & 2.981 & 2.777 & 2.780 & 2.808 & 2.840 & 2.820 & 2.777 \\
$\mathrm{H}_{2} \mathrm{O}$ & 5.000 & 5.000 & 5.000 & 5.000 & 5.000 & 5.000 & 5.000 & 5.000 \\
\hline & & & & & & & &
\end{tabular}

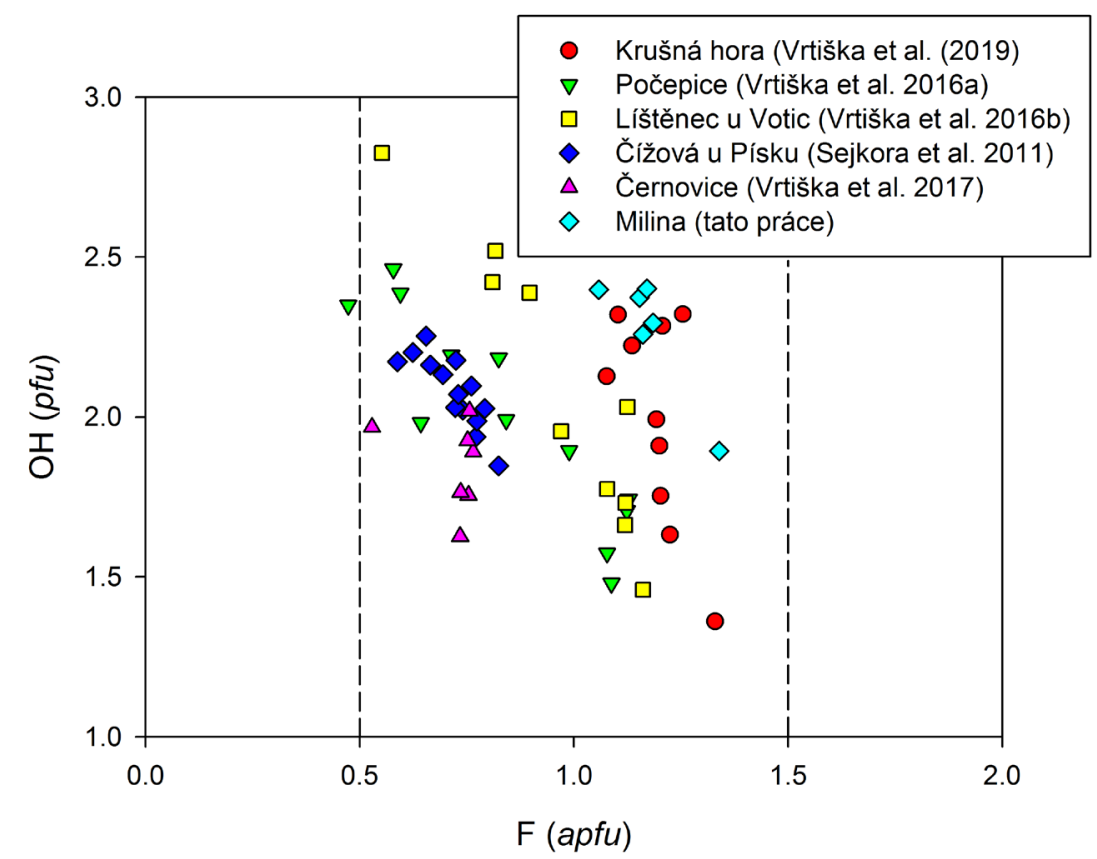

Obr. 12 Graf obsahů $F$ (apfu) vs. OH (pfu) při bázi přepočtů na 2 apfu $P$ pro fluorwavellit z Miliny (tato práce), Krušné Hory (Vrtiška et al. 2019), Černovic (Vrtiška et al. 2017), Počepic (Vrtiška et al. 2016a), Lištěnce u Votic (Vrtiška et al. 2016b) a Čížové u Písku (Sejkora et al. 2011); čárkovanou linií vyznačeny formální hranice pro wavellit/fluorwavellit. 


\section{Fluorwavellit}

V historické literatuře z Miliny uváděný wavellit (Feistmantel 1852, 1853) byl na základě studia chemického složení identifikován jako nově definovaný druh fluorwavellit (Kampf et al. 2015, 2017). Ten byl v rámci krátké doby zjištěn v České republice na lokalitách Počepice u Sedlčan (Vrtiška et al. 2016a), Líštěnec u Votic (Vrtiška et al. 2016b), Černovice u Tábora (Vrtiška et al. 2017) a Krušná hora u Berouna (Vrtiška et al. 2019). Také data publikovaná Sejkorou et al. (2011) pro wavellit z Čížové u Písku odpovídají fluorwavellitu (obr. 12).

Fluorwavellit z Miliny $v$ asociaci s allanpringitem tvoří v podobě převážně samostatných čirých jehlicovitých krystalů do velikosti $9 \mathrm{~mm}$ relikty původně radiálně paprsčitých agregátů tohoto minerálu, které byly $z$ větší části nahrazené allanpringitem a jarositem.

Rentgenová prášková data fluorwavellitu z Miliny (tab. 4) odpovídají publikovaným údajům (Kampf et al. 2015,
2017). Jeho zpřesněné parametry základní cely se dobře shodují s údaji uváděnými pro tento minerální druh (tab. 5).

Při kvantitativním studiu chemického složení fluorwavellitu z Miliny (tab. 6) byly v kationtové pozici zjištěny vedle dominantního Al (3.07 - 3.19 apfu) také malé obsahy $\mathrm{Fe}$ (do $0.007 \mathrm{apfu}$ ); obsahy F se pohybují v rozmezí 1.06 - 1.34 apfu. Na grafu obsahů $\mathrm{F}(a p f u)$ vs. $\mathrm{OH}(p f u)$ při bázi přepočtů na 2 apfu $P+S i$ (obr. 12) je zřejmé, že všechny studované vzorky z Miliny splňuji podmínky definované pro fluorwavellit. Empirický vzorec fluorwavellitu z Miliny Ize na bázi $\mathrm{P}=2$ apfu (průměr šesti bodových analýz) vyjádřit jako $\mathrm{Al}_{3.15}\left(\mathrm{PO}_{4}\right)_{2.00} \mathrm{~F}_{1.18}(\mathrm{OH})_{2.27} \cdot 5 \mathrm{H}_{2} \mathrm{O}$.

\section{Závěr}

Nález allanpringitu $v$ ordovických sedimentech $v$ zaniklém lomu Milina u Zaječova je druhým zdokumentovaným výskytem tohoto minerálu $v$ krátké době $v$ rámci České republiky. Celkově se jedná o třetí publikovaný

Tabulka 4 Rentgenová prášková data fluorwavellitu z Miliny

\begin{tabular}{rrrrrrrrrrrrrrrrrr}
\hline$h$ & $k$ & $l$ & $d_{o b s}$ & \multicolumn{1}{c}{$l_{\text {obs }}$} & $d_{c a l c}$ & $h$ & $k$ & $l$ & $d_{o b s}$ & \multicolumn{1}{c}{$l_{\text {obs }}$} & $d_{c a l c}$ & $h$ & $k$ & $l$ & $d_{o b s}$ & $l_{\text {obs }}$ & $d_{c a l c}$ \\
\hline 0 & 2 & 0 & 8.621 & 49 & 8.665 & 0 & 1 & 2 & 3.421 & 10 & 3.427 & 3 & 5 & 0 & 2.3571 & $<1$ & 2.3541 \\
1 & 1 & 0 & 8.363 & 100 & 8.412 & 2 & 4 & 0 & 3.212 & 14 & 3.219 & 2 & 0 & 3 & 2.0979 & 10 & 2.0978 \\
1 & 0 & 1 & 5.623 & 11 & 5.657 & 3 & 1 & 0 & 3.143 & 2 & 3.154 & 2 & 3 & 3 & 1.9720 & 2 & 1.9718 \\
1 & 1 & 1 & 5.355 & $<1$ & 5.378 & 1 & 2 & 2 & 3.065 & $<1$ & 3.073 & 5 & 1 & 0 & 1.9090 & $<1$ & 1.9126 \\
1 & 3 & 0 & 4.929 & 3 & 4.953 & 3 & 1 & 1 & 2.883 & 4 & 2.875 & 5 & 2 & 1 & 1.8167 & $<1$ & 1.8143 \\
2 & 0 & 0 & 4.786 & 13 & 4.811 & 2 & 1 & 2 & 2.796 & 13 & 2.791 & 1 & 8 & 3 & 1.5680 & 1 & 1.5657 \\
0 & 4 & 0 & 4.318 & 3 & 4.333 & 1 & 6 & 1 & 2.5716 & $<1$ & 2.5724 & 5 & 5 & 2 & 1.5168 & $<1$ & 1.5161 \\
2 & 2 & 0 & 4.240 & 4 & 4.206 & 1 & 7 & 0 & 2.3985 & 1 & 2.3976 & 6 & 1 & 2 & 1.4528 & $<1$ & 1.4525 \\
1 & 3 & 1 & 4.024 & $<1$ & 4.042 & & & & & & & & & & & &
\end{tabular}

Tabulka 5 Parametry základní cely fluorwavellitu pro ortorombickou prostorovou grupu Pcnm

\begin{tabular}{llllll}
\hline lokalita & reference & $a[\AA]$ & $b[\AA]$ & $c[\AA]$ & $V\left[\AA^{3}\right]$ \\
\hline Milina u Zaječova & tato práce & $9.622(7)$ & $17.330(10)$ & $6.993(8)$ & $1167.1(8)$ \\
Čížová u Písku & Sejkora et al. (2011) & $9.613(1)$ & $17.354(2)$ & $6.991(1)$ & $1166.4(3)$ \\
Silver Coin mine, Nevada (USA) & Kampf et al. (2015) & $9.6311(4)$ & $17.3731(12)$ & $6.9946(3)$ & 1170.35 \\
Počepice u Sedlčan & Vrtiška et al. (2016a) & $9.614(1)$ & $17.360(2)$ & $6.9916(9)$ & $1166.9(3)$ \\
Líštěnec u Votic & Vrtiška et al. (2016b) & $9.6259(8)$ & $17.381(2)$ & $6.9946(6)$ & $1170.3(2)$ \\
Černovice & Vrtiška et al. (2017) & $9.6285(13)$ & $17.374(3)$ & $6.9953(8)$ & $1170.2(3)$ \\
Krušná hora u Berouna & Vrtiška et al. (2019) & $9.625(2)$ & $17.367(4)$ & $6.998(3)$ & $1169.7(6)$ \\
\hline
\end{tabular}

Tabulka 6 Chemické složení fluorwavellitu z Miliny (hm. \%)

\begin{tabular}{lrrrrrrr}
\hline & mean & 1 & 2 & 3 & \multicolumn{1}{c}{5} & \multicolumn{1}{c}{5} \\
\hline $\mathrm{Al}_{2} \mathrm{O}_{3}$ & 37.70 & 37.50 & 37.98 & 37.84 & 37.70 & 37.79 & 37.39 \\
$\mathrm{Fe}_{2} \mathrm{O}_{3}$ & 0.08 & 0.08 & 0.11 & 0.08 & 0.00 & 0.14 & 0.09 \\
$\mathrm{P}_{2} \mathrm{O}_{5}$ & 33.38 & 33.97 & 33.36 & 33.47 & 33.22 & 33.59 & 32.68 \\
$\mathrm{~F}$ & 5.27 & 6.09 & 5.15 & 4.74 & 5.27 & 5.22 & 5.12 \\
$\mathrm{H}_{2} \mathrm{O}^{*}$ & 25.99 & 25.64 & 26.20 & 26.33 & 25.92 & 26.13 & 25.72 \\
$\mathrm{F=}_{-}$ & -2.22 & -2.56 & -2.17 & -2.00 & -2.22 & -2.20 & -2.16 \\
\hline total & 100.20 & 100.72 & 100.63 & 100.47 & 99.89 & 100.67 & 98.84 \\
\hline $\mathrm{Al}^{3+}$ & 3.145 & 3.074 & 3.170 & 3.148 & 3.160 & 3.132 & 3.186 \\
$\mathrm{Fe}^{3+}$ & 0.004 & 0.004 & 0.006 & 0.004 & 0.000 & 0.007 & 0.005 \\
\hline$\Sigma$ & 3.149 & 3.078 & 3.176 & 3.152 & 3.160 & 3.140 & 3.190 \\
\hline $\mathrm{P}^{5+}$ & 2.000 & 2.000 & 2.000 & 2.000 & 2.000 & 2.000 & 2.000 \\
\hline $\mathrm{F}^{-}$ & 1.178 & 1.339 & 1.153 & 1.058 & 1.185 & 1.161 & 1.171 \\
$\mathrm{OH}^{-}$ & 2.270 & 1.894 & 2.374 & 2.398 & 2.294 & 2.258 & 2.401 \\
\hline $\mathrm{F}+\mathrm{OH}$ & 3.448 & 3.233 & 3.527 & 3.456 & 3.479 & 3.419 & 3.571 \\
\hline $\mathrm{H}_{2} \mathrm{O}$ & 5.000 & 5.000 & 5.000 & 5.000 & 5.000 & 5.000 & 5.000 \\
\hline
\end{tabular}


výskyt na světě. Oba předchozí výskyty (Esserhausen v Německu a Krušná hora u Berouna) jsou na železnorudných ložiscích na puklinách železné rudy, na rozdíl od Miliny, kde se allanpringit vyskytl na puklině droby. Ve všech případech se jedná o produkt alterace wavellitu, respektive fluorwavellitu, o čemž v prípadě vzorku z Miliny svědčí také tvary agregátů nově tvořeného allanpringitu, které zachovávají původní charakter radiálně paprsčitých agregátů fluorwavellitu, včetně jeho reliktů. Vzácnost výskytu, respektive známých lokalit tohoto minerálu, Ize pravděpodobně vysvětlit na základě jeho vizuální podobnosti s jarositem, práškovitým limonitem nebo jinými železem zbarvenými práškovitými minerály (především jílovými minerály).

\section{Poděkování}

Milou povinností autorů je poděkovat RNDr. Zdeňku Dolníckovi Ph.D. z Národního muzea v Praze za spolupráci prí laboratorním studiu. Dále pak Ing. Lence Váchové z Národního muzea v Praze za zhotovení BSE fotografií. Předložená práce vznikla za finanční podpory Ministerstva kultury ČR $v$ rámci institucionálního financování dlouhodobého koncepčního rozvoje výzkumné organizace Národní muzeum (DKRVO 2019-2023/1.II.b, 00023272).

\section{Literatura}

Černý P, Černý P, VRtiška L, Malíková R, Exnar P (2015) Jarosit a doprovodné minerály z opuštěného lomu Milina u Zaječova (Česká republika). Bull mineral-petrolog Odd Nár Muz 24(2): 242-246

FEISTMANTEL K (1852) Vereinsangelegenheiten - Versammlung am 19. November. Lotos 2: 235

Feistmantel K (1853) Beitrag zur Kenntniss dem Gegend von Kruschna Hora. Lotos 3: 135

Kampf AR, Adams PM, Barwood H, Nash BP (2015) Fluorwavellite, IMA 2015-077. CNMNC Newsletter 28,
1862; Mineral Mag 79: 1859-1864

Kampf AR, Adams PM, Barwood H, Nash BP (2017) Fluorwavellite, $\mathrm{Al}_{3}\left(\mathrm{PO}_{4}\right)_{2}(\mathrm{OH})_{2} \mathrm{~F} \cdot 5 \mathrm{H}_{2} \mathrm{O}$, the fluorine analogue of wavellite. Am Mineral 102: 909-915

Kolitsch U, Bernhardt hJ, Lengauer Cl, Blass G, TillMANNS E (2006) Allanpringite, $\mathrm{Fe}_{3}\left(\mathrm{PO}_{4}\right)_{2}(\mathrm{OH})_{3} \cdot 5 \mathrm{H}_{2} \mathrm{O}$, a new ferric iron phosphate from Germany, and its close relation to wavellite. Eur J Mineral 18: 793-801

LAUgier J, Bochu B (2011) LMGP-Suite of Programs for the Interpretation of X-ray Experiments. http://www. ccp14.ac.uk/tutorial//mgp, prístup duben 2011

Mergl M, VohradskÝ P (2000) Vycházky za geologickými zajímavostmi Plzně a okolí. Koura, 272s. Mariánské Lázně

Pouchou JL, PICHOIR F (1985) "PAP" ( $\varphi \rho Z)$ procedure for improved quantitative microanalysis. In: Microbeam Analysis (J T Armstrong, ed.) 104-106, San Francisco Press, San Francisco

SeJkora J, Cícha J, JebaVÁ I (2011) Minerální asociace fosfátů z Čížové u Písku (Česká republika). Bull mineral -petrolog Odd Nár Muz (Praha) 19(1): 1-26

VRtiška L, Loun J, Malíková R, Sejkora J (2016a) Fluorwavellit a variscit z Počepic u Sedlčan (Česká republika). Bull mineral-petrolog Odd Nár Muz (Praha) 24(2): 285-297

VRTIŠKA L, MalíkovÁ R, SeJKora J (2016b) Zajímavý výskyt fosfátů v okolí Líštěnce u Votic (Česká republika). Bull mineral-petrolog Odd Nár Muz (Praha) 24(1): 114-131

VRtišKa L, SEJKora J, MalíkovÁ R (2019) Studium sekundárních fosfátů $s$ allanpringitem a tvrdýitem z opuštěného ložiska železných rud Krušná hora u Berouna (Česká republika). Bull Mineral Petrolog 27(2): 231246

VRtiška L, Sejkora J, Malíková R, Kadlec T (2017) Revize a nové nálezy fosfátů na historickém nalezišti Černovice u Tábora (Česká republika). Bull Mineral Petrolog 25(2): 277-305 